\title{
Descriptive Analysis on Flouting and Hedging of Conversational Maxims in the "Post Grad" Movie
}

\author{
Nastiti Rokhmania \\ STAIN Salatiga \\ JI. Tentara Pelajar No. 2 Salatiga, Central Java, Indonesia \\ rokhmania.nastiti@gmail.com
}

\begin{abstract}
This research is focused on analyzing flouting and hedging of conversational maxim of utterances used by the main characters in "Post Grad" movie. Conversational maxims are the rules of cooperative principle categorized into four categories; Maxim of Quality, Maxim of Quantity, Maxim of Relevance, and Maxim of Manner. If these maxims are used in conversations, the conversations can go smoothly. However, people often break the maxims overtly (flouting maxim) and sometimes break the maxims secretly (hedging maxims) when they make a conversation. This research is conducted using descriptive qualitative method based on the theory known as Grice's Maxims. The data are in form of utterances used by the characters in "Post Grad" movie. The data analysis reveals some finding covering the formulated research question. The maxims are flouted when the speaker breaks some conversational maxims when using the utterances in the form of rhetorical strategies, such as tautology, metaphor, hyperbole, irony, and rhetorical question. On the other hand, conversational maxims are also hedged when the information is not totally accurate or unclearly stated but seems informative, well-founded, and relevant.
\end{abstract}

Key words: Descriptive analysis, flouting maxims, hedging maxims, Post Grad movie.

\section{Abstrak}

Penelitian ini difokuskan pada analisis pelanggaran (flouting) dan pemagaran (Hedging) maksim percakapan ujaran yang digunakan oleh 
karakter utama dalam film "Post Grad". Maksim percakapan adalah aturan prinsip kerjasama yang terdiri dari empat kategori; Maksim kualitas, Maksim kuantitas, Maksim Relevansi, dan Maxim Cara. Jika prinsip-prinsip ini digunakan dalam percakapan, mereka bisa berjalan lancar. Namun, orang sering melanggar (pepatah mencemoohkan) maksim terang-terangan dan kadang-kadang melanggar maksim diamdiam (maksim lindung nilai) ketika mereka melakukan percakapan. Penelitian ini dilakukan di dengan metode deskriptif kualitatif berdasarkan teori yang dikenal sebagai Grice pepatah. Data tersebut berupa ucapan-ucapan yang digunakan oleh karakter dalam "Post Grad" film. Analisis data menunjukkan beberapa temuan yang mencakup pertanyaan penelitian yang dirumuskan. Kaidah yang mencemooh ketika pembicara istirahat beberapa pepatah percakapan saat menggunakan ucapan-ucapan dalam bentuk strategi retoris, seperti tautologi, metafora, hiperbola, ironi, dan pertanyaan retoris. Di sisi lain, maksim percakapan juga lindung nilai ketika informasi itu tidak benar-benar akurat atau tidak jelas dinyatakan tetapi tampaknya informatif, cukup beralasan, dan relevan.

Kata Kunci: Analisis deskriptif, pelanggaran maksim, pemagaran maksim, Film "Post Grad".

\section{Introduction}

In the daily interactions, everyone needs a good communication. A good communication can avoid misunderstanding and misinterpret between the speaker and hearer. In communication there is a theory known as the "cooperative principle". It is a principle of conversation that was presented by Grice (1975) stating that participants will contribute in a conversation such as is needed when the conversation occurs and each of them can accept the purpose of the conversation or the talk exchange. The cooperative principle explains how the people interact with others. The people who obey the cooperative principle in their conversation will make sure that what they say in their conversation gives more information about their conversation. Grice proposes four 
types of cooperative principle that is called conversational maxims. The Grice maxims are a way to explain the relation between utterance and what is known from it. The principle describes the effectiveness communication in a conversational that can be accepted by the natural social situation, and it is broken down into four. Those are Maxim of Quality, Quantity, Relevance and Manner.

Obviously, when we notice the communication around us, we will find many people do not use the Grice's Maxims appropriately. They sometimes speak and break the rule of maxim quality, quantity, relevance or even manner. Breaking the rule of the maxims is usually called flouting and hedging. We can find some flouting in the form of tautology, metaphor, irony, hyperbole, banter, sarcasm, overstatement, understatement, and rhetorical question. Furthermore, the maxim are hedged when the speaker gives an information that is not totally accurate but seem informative, well founded, and relevant, moreover the speaker copies the information from other people.

There are some reasons why people often break the maxim in the conversation. First, sometimes breaking the maxim can give more colors to the language used. Then, to draw an attention from the hearer sometimes the speaker breaks the maxim either. Breaking maxim also appreciates the language, such is found in the dialogue of novel, short story, drama, or even a movie.

This research discuss about flouting and hedging maxims used by the main character in "Post Grad" Movie. The object of this study is chosen because of some reason: first, discussing about flouting and hedging maxim in used in the movie is interesting topic. Secondly, language used in the movie has many variations, for example irony, 
hyperbole, metaphor. Thirdly, in communication people tend to speak what is in their mind without obeying the rule especially the rule of cooperative principle.

The main objectives of the study are to help the reader know and understand about flouting and hedging maxim used by the main characters on "Post Grad". Besides, this study also provides the answer from the research problems of study. (1) How the maxims are flouted by the main characters on "Post Grad" movie? (2) How the maxims are hedged by the main characters on "Post Grad" movie? This research was also supposed to give valuable contributions theoretically and practically. Theoretically, this study will give additional information to the readers; they will know the analyzing flouting and hedging maxims used in spoken language.

In pragmatics study, there are so many kinds of attractive problems that can be analyzed and discussed. It is impossible to analyze all of them. So, this research is limited on the problems by analyzing all the English conversation that is support the flouting and hedging maxims which is contained in the "Post Grad" Movie Script.

\section{Cooperative Principle}

The success of a conversation depends on the various speakers' approaches to the interaction. One of the most basic assumptions must be made for successful. Communication is that both people in conversation are cooperating. The way in which people try to make conversations works is called a co-operative principle. In Yule (1996: 37), Paul Grice defines the cooperative principle as: "Make your conversational contribution such as is required, at the stage at which is occurs, by the 
accepted purpose or direction of the talk exchange in which you are engaged"

The cooperative principle is also divided into four types, which is called Grice's Maxims. They are maxim of quality, maxim of quantity, maxim of relevance, and maxim of manner. Grice's four maxims can be expressed in synopsis as: be brief, be true, be relevant, and be clear.

\section{Maxim of Quality}

According to Grundy (2000: 74), maxim quality can be defined as truthful as required. That means the speaker should inform the truth and they are not allowed to say what they think false and give the statement that run short of proof. Here, speaker and writer are expected to say only what they believe to be true and to have evidence for what they say. However, the speaker must aware of this expectation, that the hearer expect them to honor the maxim of quality.

\section{Maxim of Quantity}

Grundy (2000:74) states that maxim of quantity as one of the cooperative principle is concerned in giving the information as it is required and is not giving the information more than it is required. The speaker just say the information as needed, it should not be less informative or more informative.

In a normal circumstance, the maxim of quantity provides that the speaker say just enough, that they do not supply less information or more that is necessary. 


\section{Maxim of Relevance}

Maxim of relevance means the utterance must be relevant with the topic that being discussed. Cutting (2002: 35) states that speakers are expected to give information about something that is relevant to what has been said before. Furthermore, Grundy (2000: 74) states that maxim of relevance is fulfilled when the speaker give information that is relevant to the topic of proceeding. Therefore, each information of the speaker or hearer must be relevant to the topic of conversation.

\section{Maxim of Manner}

According to Cutting (2002: 35), maxim of manner is when the speakers put information briefly and orderly, the speaker must avoid the obscure and ambiguous information from the hearer. Therefore, each participant must give the information directly and reasonably, and it should not be vague, ambiguous or excessive.

This maxim is related to the form of speech we use. Speaker should not to use the words they know but the listeners do not understand or say things. The speaker also should not state something in a long drawn out way if they could say it in a simple manner.

\section{Flouting Maxims}

According to Grundy (2000: 78), flouting maxim is a particularly silent way of getting an addressee to draw inference and hence recover an implicature. Moreover, Cutting (2002: 37) states that when the speaker seems not to hold on the maxims but expect the hearers to get the meaning implied, it is called flouting the maxims. The speaker says in an 
indirect speech act that implies a different function of the literal meaning of the word form; when flouting maxim, the speaker supposes to the hearer knows that their words should not be taken at the direct meaning and that they can expect the implicit meaning of the words.

According to Cutting (2002: 37) the flouting of each maxim is determined on the basis of these criteria: (1) A speaker flouts the maxim of quantity when his contribution is not as informative as is required for the current purpose of the exchange and more informative than is required. (2) A speaker flouts the maxim of quality when his contribution is not true and he says something for which lacks adequate evidence. It can be hyperbole (overstatement), metaphor, irony, banter, litotes (understatement), and sarcasm. (3) A speaker flouts the maxim of relation if his contribution is not relevant. (4) A speaker flouts the maxim of manner if contribution is not perspicuous it may be obscure, ambiguous and disorderly. According to Grundy (2000:76) can be found in tautology, metaphor, overstatement, understatement, rhetorical question and irony.

\section{Hedging Maxim}

According to Grundy (2000:79-80), hedging maxim is avoiding to make bold statement. Maxims are hedged when the information is not totally accurate but seem informative, well found and relevant. The information is taken by quoting from other person opinion.

Yule (2006: 130) states that hedges is a kind of expression which show the speaker concern to use the maxim to be a cooperative participant in the conversation. Hedges can be asserted as a words or phrase to indicate that the speaker are not really sure about his information is totally true or complete. For example, the speaker can use 
sort of or kind of as hedges on the exactness of his statement, as in this description; "His hair was kind of long" (rather than It was long) or "The cover of the book is sort of yellow" (rather than It is yellow). These are example of hedges on the quality maxim. In the italic version, we will assume that the speaker is not really sure that his hair is really long or the book's cover is really yellow, because it seems that it does not has a very good evidence for the statement.

Hedges, intentionally or unintentionally, can be employed in both spoken and written language, since they are crucially important in communication. Hedges help the speaker and writer communicate more precisely in the degree of accuracy and truth in assessment. In this case, Grundy (2000:79), hedges are markers tied to the expectation of the maxim of quantity, quality, manner, and relevance.

\section{Methodology of Research}

This research is qualitative research. This type of research is “descriptive qualitative research". According to Emzir (2011: 1), qualitative research is a research that uses deductive reasoning; it focuses on the social phenomenon. Jacob (1988) states that qualitative research is a common investigative terminology of methodologies described as ethnography, naturalistic, anthropological, field, or participant observer research, which insists the importance of the founded natural variable.

In this research, the researcher applies the documentation to collect the data. Documentation is all written materials that contain the authentic, valid, or formal form of something that can be used to complete the evidence or information. The documentation in this case is the "Post Grad" movie script. The way of collecting data are: The 
researcher selects the "Post Grad" movie script. The Researcher reads the "Post Grad" movie script. The researcher collects and takes note about the flouting and hedging maxims, which are found in the "Post Grad" movie script.

In analyzing the data, the researcher uses descriptive analysis technique to analyze the flouting and hedging maxims used in "Post Grad" movie script.

\section{Discussion}

This chapter presents the research findings and discussions. In this chapter, the analysis of the data is in line with the formulated research question. The data are analyzed based on Grice's theory of Cooperative principle which contains for maxims; maxim of quantity, maxim of quality, maxim of relevance and maxim of manner. To answer the problems, the data are classified into flouting and hedging maxims. As the next part, the discussion is done which is geared toward deriving conclusion.

There are some data obtained from the utterances in the "Post Grad" movie that can be classified into flouting maxims.

(1) 00:04:54,727 --> 00:05:00,732

Woman :Ma'am! Could you keep it down?

Maureen Malby : : And now...I'm dying.

The conversation happens in Ryden's graduation ceremony. Maureen Malby, Ryden's grandma, comes with an oxygen tank and it disturbs other visitor. When Maureen states the utterance, "and now... I'm dying", she flouts the maxim of quality. She exaggerates her 
statement which is catergorized as hyperbole or overstatement. She gives information that lies far from the truth.

(2) 00:06:23,015 --> 00:06:44,797

Ryden : Didn't I tell you? What do you see over there? What do you see right here on this wall?

Adam: Uh, white paint

Ryden: - Bookshelves!

Adam: - Oh!

Ryden states these utterances when she is looking around the apartment where she wants to live if she is accepted in Happerman \& Browning. Adam does not understand what Ryden means by asking those questions. Actually, Ryden wants to tell him what thing that she will put on that wall, but she does not give the complete information. She produces irrelevant question with the topic they are talked about.

When Ryden states the questions, "Didn't I tell you? What do you see over there? What do you see right here on this wall?" she flouts the third maxim of relation because she does not make her contribution in the conversation as relevant with the topic that being discussed, she asks questions about what Adam sees on the wall to give a clue that she will put a big book selves on there. By producing irrelevant statements, Adam as the listener cannot catch what Ryden talks about. He answers "white paint" that he looks on the wall because it's really white pain on it. If only Ryden added her question as relevant by saying, "Do you know? What thing that I will put in this wall?" Adam would understand it and maybe he will answer bookshelves or painting, not by saying white paint.

(3) 00:06:388,131 - > 00:06:44,797 
Ryden: - All my babies (a), floor to ceiling (b), organized by title. No, by author. No, by genre.

Adam: - Okay. Settle down.

Ryden states this utterance when she imagines what she will put on the floor of that apartment. When Ryden states an utterance (a) "all my babies." she uses an exaggerate statement in calling the book of her job, which make the information too more informative than what is required. It is categorized as overstatement or hyperbole by saying "all my babies". Actually, the speaker is enough to say "my books" because it seems informative.

In addition the utterance (b) "floor to ceiling" is an exaggeration statement either, which make more informative statement than it is required. It is also categorized as hyperbole or overstatement.

(4) 00:08:25,505 --> 00:08:36,872

Adam -You just calm down.

Ryden - Oh... My car! He killed my car!

No! No, no, no, no, no, no, no.

Adam- No, calm down.

Ryden states the utterance when she is in hurry to the interview and a truck suddenly hit her car whereas the truck driver does not take the responsibility to fix it or pay the insurance. The utterance "He killed my car" that is stated by Ryden, she flouts the first maxim of quality because she does not use the truth information. She says that a person killed her car, however, there is none killed her car and there is none can kill a car because car is a thing that does not have spirit. Actually, she is enough to say "he broke my car", it will be more truthful and can be believed. 
(5) $00: 25: 17,282-->00: 26: 18,238$

Mr. Davies- Are you ever gonna actually open that?

Adam- It's made a long journey from New York. I'm letting it breathe.

Mr Davies- You know, Adam, if you don't wanna go...

Adam- Don't give me that shit.

Mr. Davies-It's not like I'm gonna force you.

Adam-No, you're just gonna hate me if I don't.

It is a conversation between Adam and his father, Mr. Davies, which talks about the letter from University where Adam is accepted for the Law Scholarship. The utterance "It's made a long journey from New York. I'm letting it breathe." which is stated by Adam, is kind of an exaggeration statement. He flouts the maxim of quality, which gives the information more than it is needed. He tells the information untruthful. It is categorized as metaphor. He is talking about a letter, but he talks as it is a person. Letter is a thing that cannot make a journey or breathe but he says that he wants the letter breath and has a rest. In addition, he also flouts the maxim of manner. His father question is kind of Yes/No question but he answers it indirectly. Actually, if he does not want to open the letter he can say, "No, I'm not".

(6) 01:00:26,689 --> 01:00:39,529

Carmela: Cough it up.

Maureen: Cough what up?

Carmela: Pay the man your son's bail money.

Maureen: Are you crazy? You think if I had that kind of dough

I'd be living with you? 
The conversation happens in the police office. Carmela asks to Maureen to pay Walter's bail money. However, Maureen refuses to pay the money. She says that she does not have that much money. When Maureen states that utterance "Are you crazy?" she flouts the maxim of manner. She gives the information indirectly, ambiguously, and excessively. Actually, she can say "no way" or "I will not" to refuse Carmela's offer. Moreover, the utterance (1) also a kind of rhetorical question, even it is a kind of question but the speaker does not need an answer from the hearer. Maureen just wants to give a stress in her utterance that she refuses to do the thing.

In addition the utterance "You think if I had that kind of dough I'd be living with you?" that is stated by Maureen is also kind if rhetorical question. Where, it is also a strong statement to refuse Carmela's offer.

These are some data obtained from the utterances in the "Post Grad" movie that can be classified into hedging of conversational maxims.

(1) 00:28:49,027 --> 00:28:52,622

Ryden: Adam, so you're going into music then. Why don't you just say that?

Adam: Well, because I'm not saying that necessarily.

Ryden: So you're going to law school?

Adam: No, I'm not saying that either necessarily.

Ryden: - Then what are you saying, necessarily?

Adam: - I don't know what I'm saying. All I'm saying is that I'm opening at The Mint on Friday. Yea! 
This conversation happens when after the college reunion. When Adam tries to amuse Ryden, after she was humiliated by Jessica. Then Adam informs to Ryden that he will make a show off in the café.

Here, Adam hedges the maxim of relevant when he says "Well, because I'm not saying that necessarily", by saying "well" and "necessarily" he does not make his contribution one is relevant. He tells irrelevant information with the topic. When Ryden asks about the music, he does not answer it clearly but seems clear. He tries to move Ryden's thought about the music. However, when Ryden asks about the law school, he does not answer it clearly either, and it seems that he also tries to move to other topic which is coming back to the music. Actually, he only needs to say that he will have his first music show. He does not need to spinning round his words that make the hearer, Ryden, feels confused.

(2) 00:34:05,877 --> 00:34:19,356

Jessica Bard- You know, Ryden, I think we've got really good synergy, you and I. I know you're in a tough place right now... but I want you to remember that struggle and strife come before success. Even in the dictionary.

Jessica states the utterance when she is in Luggage Shack. She tries to compare her job and her luck to Ryden, which is very different.Jessica states the utterance, she uses some ironical statements. She uses the opposite meaning of what she means. She says that she has a synergy with Ryden, but actually she humiliates Ryden because she has a good job at Happerman \& Browning where Ryden is in the Luggage shack.

(3) 01:07:13,896 --> 01:07:39,921 
Adam- Look, I didn't get a chance to tell you... but I decided to go to Columbia. And I'm leaving tomorrow.

Ryden-What? You're going to law school? In New York?

Adam-Yeah.

Ryden- That's... That's... so great. Congratulations.

Adam- Yeah, I think it'll be... I think it'll be good.

This conversation happens when Ryden tries to ask an apologize. Then, Adam informs her that he will go to New York to take his scholarship. When Adam states the utterance "yeah, I think it'll be... I think it'll be good" he hedges the maxim of quality by saying "I think". He tries to observe the maxim of quality. He tells unsure information end he does not tell the fact what will happen in the next. In fact, he does not know whether his decision will be good for him or not.

(4) 01:19:03,872 --> 01:19:07,171

Ryden- Just out of curiosity though, do you think I'm making the right decision?

Walter- Well, you know, ever since you were a little kid... you always seemed to have it figured out. You know, you made good grades, you... kept your room neat and clean, you ate your vegetables. Can I be honest with you? I always found it a little troubling. Because, see, hon... the world's a screwy place. It doesn't play by the rules. So if you're asking me... do I think it's a good idea for you to, uh...quit your job... leave behind the only family you have... and travel 3,000 miles... to a place you've never been before? I think it's the most kick-ass idea you've 
ever had. 'Cause I think no matter where you are, you're gonna knock 'em dead.

Ryden- Thanks, Dad.

The conversation happens when Ryden packs for leaving to New York. For the last, she asks her father's opinion about her decision. Indeed, her father supports her. Walter's utterances are so exaggerated. He gives the information more than it is needed, which flouts the maxim of quantity. Actually, when he is asked about his opinion, he does not need to tell about Ryden's childhood and the world life. However, he talks more about how kind Ryden was, when she was a kid. He also talks about the decision that is made by Ryden. In addition, Walter also hedges the maxim of relation in his utterances "Well, you know, ever since you were a little kid... you always seemed to have it figured out" by using "well". He consciously makes his contribution irrelevant with the topic which is being talked before. Ryden asks about his opinion but he talks about Ryden when she was a kid.

Moreover, he also hedges the maxim of quality by using "I think" in his utterances "I think it's the most kick-ass idea you've ever ha. 'Cause I think no matter where you are, you're gonna knock 'em dead". He tries to observe the maxim of quality. He tells unsure information and he does not tell the fact that Ryden's decisions are good ideas. In fact, he does not know whether Ryden's decision are good or not, and he is not sure that Ryden can adapt in the new place easily.

\section{Findings}

After obtaining the data, the researcher finds that the maxim flout when they are delivering and maintaining their opinion, such as by 
producing the utterance in the form of rhetorical strategies, namely tautology, metaphor, overstatement, irony, and rhetorical question. When the utterance produced by using tautology, the maxim of quantity which are "make your contribution as informative as is required" and "do not make your contribution more informative than is required" are broken because in tautology the utterance that is produced is more informative that what is needed.

Besides, the maxim of quality also can be flouted when the speaker produces the utterance in the metaphor form. In this case, the speaker uses the word not in the real condition but uses symbolic or what the literary said is different with what is implied. For example, "It's (it = letter) made a long journey from New York. I'm letting it breathe". Furthermore, maxim quantity is also flouted when the speaker produces the utterance in the form of overstatement. In this case, the speaker uses exaggerated statement to convey his opinion which is too strong and appears worse than the really it is.

Therefore, the information becomes more or too informative than is required. For example, "he killed my car". Moreover, the maxim of quality that is "do not say what you believe to be false" is also flouted when the speaker produces the utterance in the rhetorical question form. In this case, the speaker informs that it is not a sincere question. It means that the speaker asks a question without any intention of getting an answer and it ends to break a sincere condition on question, the speaker wants the hearer to provide him with the indicate information. For example: "Are you crazy? You think if I had that kind of dough I'd be living with you?" and so on. Besides, the point of maxim of quality "do not say what you believe to be false" is also flouted when the speaker 
produces the utterance in the ironical form. In this case, the thing that is spoken by the speaker expresses one's meaning by saying something, which is direct opposite of one's thoughts, in order to make one's remark to be forceful. For example, "I think we've got really good synergy, you and $I$.

However, maxim of manner is also flouted when the speaker produces the utterance indirectly, ambiguously, and excessively. In this case the speaker intends to inform to the hearer about something but the speaker uses indirect statement that implies for something. For example: "Are you crazy? You think if I had that kind of dough I'd be living with you?". Besides, the maxim of relevance also can be flouted when the speaker produces the utterance that is not relevance with the topic of what the speaker talks about.

In addition, the researcher finds that the maxims hedges when the utterance produced is not totally accurate but it seems informative, wellfounded, and relevant. In this case, the maxim quantity that is "make your contribution as informative as is required" hedged by the speaker when they produce the information that is not as much or not as precise as it might be expected. For example: "I think it's the most kick-ass idea you've ever had." By using the phrase "It think..." it seems that the speaker do not tell the information as precisely as the hearer might be expected.

Moreover, the maxim of relevance is hedged when the speaker produces the utterance is not as relevant at the stage at which it occurs. For example: "Well, you know, ever since you were a little kid... you always seemed to have it figured out." The signal word "well" changes the topic that is spoken by the speaker before, but it does not seem that 
the speaker breaks the maxim of relevance. Thus how, in the "Post Grad" movie, the characters hedge the maxims of quantity and relevance.

\section{Conclusion}

After obtaining and analyzing the data, the researcher presents the conclusion at the last part of this paper. The conclusion is drawn based on the formulated research question. Firstly, the main characters of "Post Grad" movie flout the conversational maxims when they broke the utterance in delivering their opinion with other character by using the utterances in the form of rhetorical strategies, such as: tautology, metaphor, overstatement, rhetorical question, and irony. Secondly, the main characters of "Post Grad" movie also hedge the conversational maxims in their conversations. They hedge the maxim of quantity and the maxim of relevant when the information in their utterance are not as much or as precise as it might be expected and it is not as relevant at the stage at which it occure.

\section{References}

Cook, Guy. 1989. Discourse. New York: Oxford University Press

Diyanni, Robert. 2004. Literature: Approaches to Fiction, Poetry, and Drama. New York. McGraw-Hill

Cutting, Joan. 2002. Pragmatics and Discourse, a Resource Book for Student. New York: Routledge.

Emzir, Prof.Dr. 2011. Metodologi Penelitian Qualitative "Analisis Data”. Jakarta: Rajawali Press.

Grice, Paul. 1989. Study in the Way of Words. Harvard University Press. 
Grundy, Petter. 2000. Doing Pragmatics. London: Arnold, a member of the Hodder Headline Group

Leech, Geoffrey. N. 1983. Principle of Pragmatic. New York: Longman Yule, George. 1988. Discourse Analysis. Cambridge: Cambridge University Press

... . 1996. Pragmatic. Oxford: Oxford University Press

... . 2006. The Study of Language. New York: Cambridge University Press.

http://www.aect.org/edtech/ed1/41/41-01.html

http://www.awinlanguage.blogspot.com/2012/05/hedging-of-maxim.html accessed on September, 25th 2012 at $23.01 \mathrm{pm}$

http://universitychic.com/article/qa-post-grad-screenwriter-kelly-fremon, accessed on August, $6^{\text {th }} 2012$ http://www.huffingtonpost.com/2012/05/16/7-post-grad-movies-foryo_n_1521448.html accessed on July, 26th 2012 http://www.imdb.com/title/tt1142433/ , accessed on July, 26 ${ }^{\text {th }} 2012$ http://www.okstate.edu/ag/agedcm4h/academic/aged5980a/5980/newpag e110.htm http://www.wvup.edu/elamb/Emily'sPDFfiles/102\%20ADS/Unit\%202\% 20-\%20Literary\%20Analysis\%20-Basic\%20Elements.pdf, http://www.wikipedia.com/postgradmovie 